"Factors affecting earnings response coefficient in Jordan: applied study on the Jordanian industrial companies"

\begin{tabular}{|c|c|}
\hline AUTHORS & $\begin{array}{l}\text { Hanan Al Awawdeh } \\
\text { Saad A. al-Sakini (D http://orcid.org/0000-0002-9510-4050 } \\
\text { Mahmoud Nour }\end{array}$ \\
\hline ARTICLE INFO & $\begin{array}{l}\text { Hanan Al Awawdeh, Saad A. al-Sakini and Mahmoud Nour (2020). Factors } \\
\text { affecting earnings response coefficient in Jordan: applied study on the Jordanian } \\
\text { industrial companies. Investment Management and Financial Innovations, 17(2), } \\
\text { 255-265. doi:10.21511/imfi.17(2).2020.20 }\end{array}$ \\
\hline DOI & http://dx.doi.org/10.21511/imfi.17(2).2020.20 \\
\hline RELEASED ON & Wednesday, 01 July 2020 \\
\hline RECEIVED ON & Monday, 24 February 2020 \\
\hline ACCEPTED ON & Tuesday, 02 June 2020 \\
\hline LICENSE & $\begin{array}{l}(\mathrm{c}) \mathrm{EY} \\
\text { This work is licensed under a Creative Commons Attribution } 4.0 \text { International } \\
\text { License }\end{array}$ \\
\hline JOURNAL & "Investment Management and Financial Innovations" \\
\hline ISSN PRINT & $1810-4967$ \\
\hline ISSN ONLINE & $1812-9358$ \\
\hline PUBLISHER & LLC "Consulting Publishing Company "Business Perspectives" \\
\hline FOUNDER & LLC "Consulting Publishing Company "Business Perspectives" \\
\hline
\end{tabular}

NUMBER OF REFERENCES

35

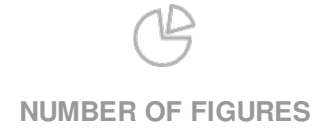

0

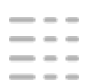

NUMBER OF TABLES

3

(C) The author(s) 2023. This publication is an open access article. 


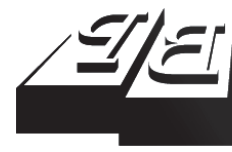

BUSINESS PERSPECTIVES

(2)

LLC "CPC "Business Perspectives" Hryhorii Skovoroda lane, 10, Sumy, 40022, Ukraine www.businessperspectives.org

Received on: $24^{\text {th }}$ of February, 2020 Accepted on: $2^{\text {nd }}$ of June, 2020 Published on: $1^{\text {st }}$ of July, 2020

(C) Hanan Al Awawdeh, Saad A. alSakini, Mahmoud Nour, 2020

Hanan Al Awawdeh, Ph.D. in Accounting, Associated Professor, Department of Accounting, Isra University, Amman, Jordan.

Saad A. al-Sakini, Ph.D. in Accounting, Associated Professor, Department of Accounting, Isra University, Amman Jordan. (Corresponding author)

Mahmoud Nour, Ph.D. in Finance, Professor, Department of Banking \& Finance, Isra University, Amman, Jordan.

\section{FACTORS AFFECTING EARNINGS RESPONSE COEFFICIENT IN JORDAN: APPLIED STUDY ON THE JORDANIAN INDUSTRIAL COMPANIES}

\begin{abstract}
Earnings Response Coefficient (ERC) reflects the market response to the company's published earnings. It also reflects the quality of the company's profits. This study aims to examine the factors affecting ERC in Jordan based on a sample of 17 Jordanian industrial companies listed on the Amman Stock Exchange during 2012-2018. The dependent variable of this study is the Earnings Response Coefficient (ERC). Five independent variables or factors were selected for testing their impact on the dependent variable, namely, leverage ratio, systemic risks, company's size, company's growth opportunity, and the company's profitability. The results of panel data regression analysis showed that for companies with a higher leverage ratio, the market is less responsive to the change in their profits than those with a higher leverage ratio. Systematic risk has a negative and significant effect on ERC, which means that high systemic risks lead to a reduction in the ERC. The company's size has no significant impact on ERC, indicating the irrelevance of the relationship between the size of Jordanian industrial companies and their profits. The company's growth opportunity has a negative and significant impact on ERC, which means low market-to-book ratio and higher growth opportunities resulting in higher ERC. Finally, the company's profitability measured by return on assets (ROA) has a positive and important impact on ERC, suggesting that higher profitability increases ERC. The study highlighted the importance of ERC and recommended that companies take the needed measures to increase their ERC. It also recommended raising investors' awareness.
\end{abstract}

\section{Keywords}

ERC, earnings, leverage, systemic risk, beta, size, growth, $\mathrm{ROA}$

\section{JEL Classification $\quad$ G12, G14, M49}

\section{INTRODUCTION}

Accounting earnings are one of the most important items disclosed in companies' financial statements, as they constitute the result of all the operational, investment, and financial activities carried out by the company during the financial period. This makes profits to the attention of all users of the financial statements (K. Chan, L. Chan, Jegadeesh, \& Lakonishok, 2006).

The publication of any events containing company information, such as earnings announcements, affects stock prices and volume of trading in the financial market. One of the indicators used to assess the importance of accounting information is the reaction of investors towards it when it is announced, and its implications on stock prices. The volatility of stock prices also increases during the release of the financial statements period compared to previous periods. This reflects the market's response to stock prices to understand the Earning Response Coefficient (ERC). The ERC reflects the market response to 
the company's published earnings information, which can be observed by moving stock prices during the announcement period (Diantimala \& Yossi, 2008).

Since ERC reflects the reaction to the company's published earnings, it also reflects the quality of the company's earnings. The value of ERC determines how powerful is the reaction to information or good/bad news contained in the earnings (Suwarno, Tumirin, \& Zamzam, 2017). The high value of ERC means that the earnings can provide important information to the investors to make investment decisions, while the low value of the ERC means that the earnings cannot provide important information to the investors (Ambarwati, 2008).

Previous researches indicated several factors that may affect ERC. The systematic risk seems to have a negative effect on ERC. Investors will respond negatively to companies with a high leverage ratio due to creditors' priority over stockholders. Larger companies will tend to get more trust from investors and higher ERC. Companies with high growth opportunities have high ERC because of their growth potential. Companies with good profitability tend to have higher ERC.

The importance of investigating factors affecting ERC arises mainly from the need to enhance the confidence of a firm's stakeholders in accounting information announcements, enabling them to make rational and informed decisions. Moreover, Earnings Response Coefficient is considered a measure of the market response capacity to earning information and because it is an important indicator of the quality of earnings so that the higher the coefficient indicates a higher quality of earnings. Accordingly, it is important to understand the factors affecting the Earnings Response Coefficient to improve it and its impact on all stakeholders and increase earnings quality.

Based on the foregoing, this study aims to test the factors affecting ERC in Jordan based on a sample of Jordanian Industrial Companies during 2012-2018.

The contribution of this study is: as a development and application groundwork in implementing knowledge and theory; as a continuing study about ERC in Jordan; to give information to investors and other users of financial information about the importance of ERC; to give information and illustration to the companies in making financial decisions affecting the above factors.

The rest of this study has been structured as follows: section 1 reviews previous studies related to the subject of the study; section 2 discusses the study methodology, including the study sample, the study model, the definition of study variables, and the development of hypotheses; section 3 discusses the results of the study, including the descriptive statistics and regression analysis results; and final section shows the most important conclusions and recommendations of the study.

\section{LITERATURE REVIEW}

The ERC and has attracted considerable attention from researchers, and several previous studies have tested factors affecting ERC. The following subsections discuss literature on ERC and the factors affecting ERC.

\subsection{Earnings Response Coefficient}

Earnings are considered an important factor that determines the companies' performance. The company's management is concerned with earnings be- cause it is the main objective of the company's establishment, a major input to the decision-making process, and earnings are among the most important standards for evaluating the management performance (Peasnell, Pope, \& Young, 2000).

Shareholders and corporate boards are interested in earnings to better assess the company's value, better evaluate its performance, make the right investment decisions (Gaio \& Raposo, 2011), and assess the efficiency and performance of management (Lev, 2003). Investors consider earnings as a key indicator of the market's share price. From an evaluative point 
of view, earnings can be seen as a brief measure of the company's performance, and one of the most important accounting information that companies announce to investors (Wang \& Yang, 2013). It is also a key source of financial information in capital markets, as the financial analysts rely on profits to set their future stock forecasts (Siegel, 1982).

According to financial theory, most of the company's valuation and forecast models are based on accounting profits, which makes accounting profits one of the most important information disclosed by the company and makes it highly informative content. Efficient Market Hypothesis assumes that the market shows a quick reaction to new information. The share price reflects the full and immediate company's available information (Mashayekhi \& Aghel, 2016).

Earnings announcement in the financial reports is a key indicator of profitability. The earnings are a good indicator of the company's future cash flows and provide important information on the company's economic performance compared to cash flows (Dechow, Kothari, \& Watts, 1998; Schipper \& Vincent, 2003).

Previous researches indicated a strong relationship between stock prices and accounting earnings. Collins (1989) confirmed that the publication of any events containing company information, such as earnings announcements, affects stock prices and the volume of trading in the financial market.

Naimah et al. (2006) indicated that one of the indicators used to assess the importance of accounting information is investors' reaction towards it when it is announced and its implications on stock prices. The volatility of stock prices also increases during the release of the financial statements period compared to previous periods. This reflects the market's response to stock prices to understand the Earning Response Coefficient.

The ERC reflects the market response to the company's published earnings information, which can be observed by moving stock prices during the announcement period (Diantimala \& Yossi, 2008). Since this coefficient reflects the reaction to the company's published earnings, it also reflects the quality of the company's earnings. The value of ERC deter- mines how powerful is the reaction to the information or good/bad news contained in the earnings (Suwarno et al., 2017).

The high value of ERC means that the earnings can provide important information to the investors to make investment decisions, while the low value of the ERC means that the earnings cannot provide important information to the investors (Ambarwati, 2008).

Scott (2003) indicated that the Earnings Response Coefficient is the quantity of abnormal stock returns in response to the unexpected earnings reported by the company. Regression between stock price and profit accounting is the essence of ERC. Cumulative Abnormal Return (CAR) is used as a proxy for stock price, while Unexpected Earning (EU) is a proxy of accounting profits.

Shah and Hussain (2012) and Sandi (2013) suggested that ERC plays a vital role in analyzing and estimating stock price while using financial information of the companies. They indicated that investors could easily use this financial information to evaluate firms and assess which company is more profitable and less risky.

Farooq, Shehata, and Nathan (2018) examined the ERC of non-financial companies listed in the Middle East and North Africa region during 2003-2013. The results of the study showed that the ERC was positive and important for sample companies, as well as for different countries and sectors. The results also showed that ERC increases with the increase of the measurement period, which means the increase of the information contained in stock prices with the increase of measurement period. The concluded that the importance of the declared profits to the longterm investors in the Middle East and North Africa (MENA) region.

\subsection{Factors affecting Earning Response Coefficient (ERC) and the development of study hypotheses}

Literature includes a wide variety of factors or determinants that may affect the Earnings Response Coefficient. According to Scott (2015), the ma- 
jor part of ERC is attributed to many factors, including company's size, growth opportunities, earnings persistence, systematic risk, and capital structure.

Previous research indicated that many factors have a negative or positive impact on ERC. In the following context, the most variables or factors affecting ERC shall be reviewed that will be included in this study:

(I) Leverage ratio: Companies with a high leverage ratio have a high debt volume, so increasing the company's profits gives creditors an additional safety factor about the company's ability to pay off debts. Arifin (2017) indicated that leverage might have different implications for the company's shareholders who may react negatively to the company's higher profits because these profits will be directed primarily to creditors who have priority over dividends to shareholders. Several studies, such as Mulyani, Nur, and Andayani (2007) and Etty (2008), found that the leverage ratio has a negative impact on ERC. Based on the above, the first hypothesis of the study can be formulated as follows:

\section{H1: Leverage ratio has no impact on ERC.}

(II) Systemic risks: Systemic risks reflect risks that impact all companies in the market and cannot be eliminated by diversifying portfolio assets. The level of systemic risk for companies is measured by the Beta coefficient, which reflects the sensitivity of corporate returns relative to the market return. Collins and Kothari (1989) confirmed that there is a relationship between the Beta coefficient and ERC. The studies of Easton and Zmijewski (1989), Mulani et al. (2007), Rifika (2015) also showed that systemic risk has a negative impact on the value of the ERC. The second study hypothesis can be formulated as follows:

\section{H2: Systemic risks have no impact on ERC.}

(III) Company size: The company's size reflects the company's total assets at the end of the year. The size of a company is seen as an indicator of information content, as large companies have more information than small firms. Large companies are usually the focus of shareholders and investors' attention, so the market response is significant to the profits declared by such companies (Suwarno et al., 2017). Many studies have confirmed the positive relationship between the size of the company and ERC, such as the study of Kusuma, Nugroho, and Setiyo (2010). Based on the above, the third hypothesis of this study can be formulated as follows:

\section{H3: The company size has no impact on ERC.}

(IV) Growth opportunity: Companies having high growth opportunities usually distribute lower profits to enhance their ability to finance their investments internally through the retained profits (Arfan, Antarsari, \& Ira, 2008). The growth opportunity means the company's future possibilities to develop its operations to increase its value and achieve greater profits for future investors. Based on the above, the company's growth opportunities might affect ERC (Suwarno et al., 2017). Several previous studies, such as Collins and Kothari (1989), found that the company's growth opportunities have a positive impact on ERC because high-growth companies will be able to make higher profits in the future, which creates positive response by investors to profits increase. Lower company's growth opportunity, measured by market to book value ratio, indicates higher growth opportunities and higher ERC (Andyani \& Mulyani, 2007). The fourth hypothesis of this study can be formulated as follows:

\section{H4: Growth opportunity has no impact on ERC.}

(V) Company profitability: Profitability, measured by dividing net profit on total assets (Suwarno et al., 2017), reflects the company's ability to make profits (Sri, 2014), reflecting the company's ability to generate profits from liabilities and equity invested in assets. Several studies, such as Pamungkas and Bayu (2014), pointed out that profitability significantly affects the ERC. The study of Suwarno et al. (2017) also found that the company's profitability had a negative and significant impact on the ERC. Based on the above, the fifth hypothesis of this study can be formulated as follows:

H5: Company profitability has no impact on ERC. 


\subsection{Empirical studies on factors affecting ERC}

Widiatmoko and Indarti (2019) tested the impact of earnings persistence, growth, systemic risks, capital structure, and company size on ERC. The study used a sample of 50 real estate companies listed on the Indonesian Stock Exchange during 2011-2014. The regression analysis results indicated that earnings persistence and capital structure had a positive and significant impact on ERC, while the company's growth had a negative impact on ERC. The systemic risks and company size had no impact on ERC.

Kurniawati and Dwimulyani (2018) examined factors that affect the quality of corporate profits measured by the ERC, in addition to measuring the impact of those factors and ERC on the size of trading in the stock market. The study is based on 56 industrial companies listed on the Indonesian Stock Exchange from 2012 to 2016. The study examined three factors, namely company's growth, systemic risks, and earnings persistence. Using the Panel Data Regression method, the study found that the company's growth negatively affected ERC, while the systemic risks and earnings persistence had a positive impact on the ERC. The study also found that the ERC negatively affects trading volume and that the company's growth and continuity of profits had a direct impact on trading volume.

Arifin (2017) examines the factors affecting ERC, including leverage ratio, systemic risks, growth opportunities (market value-to-book value ratio), and company size. The study sample included 12 automobile manufacturers listed on the Indonesian Stock Exchange from 2008 to 2012. Using multiple linear regression models, the study results showed that the leverage ratio, growth opportunities, and company size have a significant impact on the Earnings Response Coefficient. The impact of the leverage ratio was negative on the ERC, while the growth opportunities and the company size had a positive impact on ERC.

Mashayekhi and Aghel (2016) aimed to test factors affecting ERC usage in emerging markets, including the company's size, profit growth, and earnings persistence. Based on a sample of 82 Iranian companies listed on the Tehran Stock Exchange from 2001 to 2012, the study found that the company's size and profit growth had a positive and significant impact on ERC, while earnings persistence had no impact on ERC.

Hasanzade, Darabi, and Mahfoozi (2013) aimed to identify the factors affecting ERC using a sample of 202 companies listed on the Tehran Stock Exchange from 2006 to 2012. Using a common regression analysis, the study found that the quality of earnings, growth opportunities and profitability have a positive and important impact on ERC. Systemic risks had a negative and significant impact on ERC. Indebtedness had no impact on ERC.

\subsection{Conclusion of previous studies}

Reviewing the previous literature and studies on ERC reveals the scarcity of studies on the factors affecting ERC in Arab countries, in general, and in the Jordanian market, in particular.

Further researches would be needed targeting Arab countries. This study adds to the previous studies in several aspects: it provides new applied evidence about the factors affecting ERC in emerging markets; it uses five independent variables together, while many of the previous studies used three to four independent variables of factors.

\section{METHOD}

\subsection{The study community and sample}

The study community includes all industrial public companies listed on the Amman Stock Exchange, which reached 47 companies at the end of 2018 . These companies are spread over nine subsectors, namely pharmaceuticals, medical industries, chemical industries, printing and packaging, food, beverages, tobacco and cigarettes, extractive and mining industries, engineering and construction industries, electrical, clothing industries, leather and fabric industries.

The sample of the study is based on the availability of three basic conditions: (1) the availability of financial statements during 2012-2018, (2) the availability of company's closing prices for five days before and after the date of issuance its financial statements, (3) 
the company should have several trading days more than 200 days per year for all the years of the study to avoid the problem of thin trading. By applying the above criteria, 17 Jordanian industrial companies listed on the Amman Stock Exchange were included in the study sample.

\subsection{Study model}

Based on the objectives of this study by testing the most important factors affecting Earnings Response Coefficient, and the methodology used in several previous studies that tested the determinants of ERC, including Widiatmoko and Indarti (2019), Kurniawati and Dwimulyani (2018), Farooq et al. (2018), Suwarno et al. (2017), Arifin (2017), Mashayekhi and Aghel (2016). The standard model of the current study can be developed as follows:

$$
\begin{aligned}
& E R C_{i t}=\beta_{0}+\beta_{1} L E V_{i t}+\beta_{2} \text { BETA }_{i t}+ \\
& +\beta_{3} S_{Z I E} E_{i t}+\beta_{4} G R T H_{i t}+\beta_{5} R O A_{i t}+\varepsilon_{t},
\end{aligned}
$$

where $E R C_{i t}$ is the Earnings Response Coefficient $(E R C)$ of the company $i$ during the period $t, L E V_{i t}$ is the leverage ratio of the company $i$ during the period $t, B E T A_{i t}$ is the systemic risks measured by beta coefficient for the company $i$ during the period $t, S I Z E_{i t}$ is the size of the company $i$ assets during the period $t$ and $G R T H_{i t}$ is the growth opportunities of the company $i$ during the period $t$, and $R O A_{i t}$ is the return on assets of the company $i$ during the period $t$.

\subsection{The definition of the study variables}

\subsubsection{Earnings Response Coefficient (ERC)}

ERC reflects the market's response to the earnings published by the company through the share price movement during the declaration of earnings time (Diantimala \& Yossi, 2008). The higher ERC, the higher ability of profits to provide important information to investors for investment decision-making (Ambarwati, 2008). Thus, ERC is an indicator of the market's response to the profits information issued by the company (Assagaf, Murwaningsari, Gunawan, \& Mayangsari, 2019). ERC is obtained through regression of stock price proxy and accounting earnings. In this regard, Cumulative Abnormal Return (CAR) is used as a proxy for stock price, while Unexpected Earning (EU) is used as a proxy for accounting earnings.

ERC will be measured in several phases according to the method used in the previous studies, such as Rizki and Rosyidiana (2017), Suwarno et al. (2017), Santoso (2015), and Paramita (2012) as follows:

a. Calculation of the daily earnings per share $R_{i t}$ by calculating the change if share price as follows:

$$
R_{i t}=\frac{C P_{i t}-C P_{i t-1}}{C P_{i t-1}},
$$

where $C P_{i t}$ is the closing price of the () company's share on date $t$, and $C P_{i t-1}$ is the closing price of the company's $i$ stock the day before $t-1$.

b. Calculation of market earnings $R M_{t}$ by calculating the change in the market index as follows:

$$
R M_{t}=\frac{I N D E X_{t}-I N D E X_{t-1}}{I N D E X_{t-1}}
$$

where INDEX is the indicator of the market on date $t$ and $I N D E X_{t-1}$ is the index of the market on the day before $t-1$.

c. Calculation of abnormal returns of the company's share $A R_{i t}$ according to the difference between the company's $i$ share return $R_{i t}$ and the market return $R M_{t}$ as in the following equation:

$$
A R_{i t}=R_{i t}-R M_{t},
$$

d. Calculation of abnormal accumulated returns per share $C A R_{i t}$ based on the date of declaration of profits by considering five days before the declaration of profits and five days after the declaration date of company $i$, forming a period of 11 days. This period is appropriate to discover any unnatural returns per share as a result of the declaration of profits.

$$
C A R_{i t}=C A R(-5,+5)=\sum_{-5}^{+5} A R_{i t} .
$$

e. Calculation of unexpected earnings $U E_{i t}$, which is the change in the current and past company's profits according to the following equation: 


$$
U E_{i t}=\frac{U E_{i t}-U E_{i t-1}}{U E_{i t-1}},
$$

where $U E_{i t}$ is the net profits of company $i$ in the period $t$, and $U E_{i t-1}$ is the net profits of company $i$ in the previous period $(t-1)$.

f. Calculation of the impact of the unexpected earnings $U E_{i t}$ on the accumulated unnatural earnings per share $C A R_{i t}$ by the regression analysis according to the following equation:

$$
C A R_{i t}=\beta_{0}+\beta_{1} U E_{i t}+\varepsilon_{t},
$$

where $C A R_{i t}$ is the abnormal accumulated returns per share of company $i$ in the period $t$, and $U E_{i t}$ is the unexpected profits of company $i$ in the period $t$. The coefficient $\beta_{1}$ reflects the size of ERC.

\subsubsection{Factors affecting ERC}

This study uses five independent variables that represent factors affecting ERC. Table 1 summarizes the independent variables used in the study:

\begin{tabular}{|c|c|c|}
\hline Variable & Description & $\begin{array}{l}\text { Measurement } \\
\text { formula }\end{array}$ \\
\hline $\begin{array}{l}\text { Leverage } \\
\text { ratio (LEV) }\end{array}$ & $\begin{array}{l}\text { The leverage ratio shall } \\
\text { be measured in this } \\
\text { study by dividing the } \\
\text { total liabilities on total } \\
\text { assets }\end{array}$ & $L E V=\frac{\text { Total liabilities }}{\text { Total assets }}$ \\
\hline $\begin{array}{l}\text { Systemic } \\
\text { risks (BETA) }\end{array}$ & $\begin{array}{l}\text { Systemic risk will be } \\
\text { measured by beta } \\
\text { coefficient, using } \\
\text { Capital Assets Pricing } \\
\text { Model (CAPM). } R_{i t} \text { is the } \\
\text { return on the company } \\
i \text { share in period } t \text {. } \\
\left(R M_{t}\right) \text { is the return on } \\
\text { the market portfolio in } \\
\text { period } t . B_{0} \text { represents } \\
\text { the risk- free return, } \\
\text { and }\left(B_{1}\right) \text { represents } \\
\text { Beta Coefficient for } \\
\text { company } i \text { in period } t\end{array}$ & $R_{i t}=\beta_{0}+\beta_{1} R M_{t}+\varepsilon_{t}$ \\
\hline $\begin{array}{l}\text { Company } \\
\text { size (SIZE) }\end{array}$ & $\begin{array}{l}\text { The natural logarithm } \\
\text { will measure the size of } \\
\text { the company for total } \\
\text { assets }\end{array}$ & $S I Z E=\ln ($ total assets $)$ \\
\hline $\begin{array}{l}\text { Growth } \\
\text { opportunity } \\
\text { (GRTH) }\end{array}$ & $\begin{array}{l}\text { The company's growth } \\
\text { opportunities will } \\
\text { be measured by the } \\
\text { market to book value } \\
\text { ratio }\end{array}$ & GRTH $=\frac{\text { Market value }}{\text { Book value }}$ \\
\hline $\begin{array}{l}\text { Company } \\
\text { profitability } \\
\text { (ROA) }\end{array}$ & $\begin{array}{l}\text { Profitability can be } \\
\text { measured by dividing } \\
\text { net profit on total } \\
\text { assets }\end{array}$ & $R O A=\frac{\text { Net income }}{\text { Total assets }}$ \\
\hline
\end{tabular}

Table 1. Summary of the study dependent variables

\section{RESULTS}

\subsection{Descriptive statistics}

Table 2 shows a summary of the descriptive statistics of the study variables. Based on Table 2, the average ERC of the sample companies during 20122018 was about $4.9 \%$, reflecting the general decline of ERC, as the market responds by not more than $5 \%$ to the change in the profits declared by the company. The ERC value ranged from $-50.66 \%$ to $45.27 \%$, with a standard deviation of 0.2576 , which indicates a significant variation in ERC from year to year and from one company to another.

The leverage ratio reached, on average, 45.4 percent, reflecting a high leverage ratio in the Jordanian industrial sector. The leverage ratio ranged from $9.5 \%$ to $78.3 \%$, with a standard deviation of $20.45 \%$. This indicates a significant variation in leverage ratios from one company to another and over the years of the study.

Beta coefficient, which measures the systemic risks in this study, is, on average, about 0.47 , which means that the movement of Jordanian industrial companies' earnings does not exceed half movement in the earnings of the market portfolio. This indicator indicates the low-risk volume in Jordanian industrial shares as the margin of movement in the share prices is relatively low. At the same time, it indicates a decline in the returns on the shares of those companies. The value of the beta coefficient ranged from -0.094 to 2.78 , with a standard deviation of 0.564 , which confirmed a significant difference in the level of risk from one company to another and from year to year. At the same time, it indicates a decline in the returns of such companies' shares. Beta coefficient ranged from -0.094 to 2.78 , with a standard deviation of 0.564 . This confirms a significant difference in the level of risk from one company to another and from year to year.

For company size, the results indicate that the average size of sample companies during the study period was 7.73 natural logs, or JD 197.8 million. The size of companies ranged from 6.75 logarithms (JD5.65 million) to 9.25 logarithms (JD 1,798.6 million), with a standard deviation of 0.66 . This indicates a significant disparity in sample companies' sizes. 
Table 2. Descriptive statistics of the study variables

\begin{tabular}{|c|c|c|c|c|c|c|}
\hline Statistics & ERC & LEV & BETA & SIZE & GRTH & ROA \\
\hline Mean & 0.0489 & 0.4539 & 0.4714 & 7.7313 & 0.9299 & 0.01255 \\
\hline Median & 0.0176 & 0.4082 & 0.2746 & 7.7334 & 0.6043 & 0.0130 \\
\hline Maximum & 0.4527 & $0.831 \mathrm{~V}$ & 2.7850 & 9.2549 & 10.2840 & 0.2942 \\
\hline Minimum & -0.5066 & 0.0952 & -0.0936 & 6.7522 & 0.1329 & -0.2224 \\
\hline Std. dev. & 0.2576 & 0.2045 & 0.5642 & 0.6596 & 1.6226 & 0.0797 \\
\hline Skewness & 0.4601 & 0.7123 & 2.3903 & 0.6639 & -3.8242 & 0.6377 \\
\hline Kurtosis & 3.1744 & 3.0095 & 6.5282 & 2.7662 & 4.8824 & 7.6468 \\
\hline Jarque-Bera & 5.009 & 10.065 & 64.848 & 9.012 & 76.806 & 115.131 \\
\hline Probability & 0.0817 & 0.0065 & 0.0000 & 0.0110 & 0.0000 & 0.0000 \\
\hline Observations & 119 & 119 & 119 & 119 & 119 & 119 \\
\hline Cross-sections & 17 & 17 & 17 & 17 & 17 & 17 \\
\hline
\end{tabular}

With regard to the growth opportunities of the company, the average market-to-book value ratio of the sample companies during the study period was about 0.93 , which reflects that the shares of industrial companies are traded in the financial market at market prices below their book value, and are, therefore, considered underpriced. Based on this ratio, it can be said that the shares of these companies face high growth opportunities. The ratio of the market to book value ranged from 0.13 to 10.28 , with standard deviation of 1.62 , which indicates a significant difference in the growth opportunities facing Jordanian industrial companies.

Finally, the average returns on assets for the sample companies during the study period were about $1.25 \%$, ranging from $-22.2 \%$ to $29.4 \%$, with standard deviation of $7.97 \%$. This reflects the wide disparity in the profitability of sample companies.

\subsection{Regression analysis results}

Table 3 shows the results of the panel data regression of the study model, which tests the factors affecting ERC. This method was used because it fits the study data, including 17 Jordanian industrial companies over 7 years (2012-2018).

Based on Table 3, it can be concluded that a negative and statistically significant impact of the leverage ratio on ERC can be observed. This means that for companies with higher leverage, the market is less responsive to the change in their profits than for those with a higher leverage ratio. This finding is consistent with the results of several previous studies, such as Mulyani et al. (2007), Etty (2008), and Arifin (2017).
The results also show that there is a negative and statistically significant effect of Beta coefficient on ERC, which means that high systemic risks lead to a reduction in the ERC. Contrary to expectations, the results showed that the company size has no statistically significant impact on ERC. Regarding the company's growth opportunities, it has a negative and statistically significant impact on ERC, which means low market-to-book ratio and higher growth opportunities, resulting in higher ERC.

Finally, the results show that the profitability of the company (return on assets) has a positive and significant impact on ERC, which means that the higher profitability of the company increases ERC.

Table 3. The results of the regression analysis of the study model

\begin{tabular}{|c|c|c|c|}
\hline Variable & Coefficient & t-statistic & Prob. \\
\hline C & -0.1297 & -1.6392 & 0.1040 \\
\hline LEV & -0.3545 & -5.0014 & 0.0000 \\
\hline BETA & -0.0717 & -4.2760 & 0.0000 \\
\hline SIZE & 0.0091 & 0.7996 & 0.4256 \\
\hline GRTH & -0.0154 & -2.4501 & 0.0158 \\
\hline ROA & 0.4457 & 2.9692 & 0.0036 \\
\hline \multicolumn{4}{|c|}{ Regression statistics } \\
\hline Dependent variable & \multicolumn{3}{|c|}{ ERC } \\
\hline Method & \multicolumn{3}{|c|}{ Pooled EGLS } \\
\hline Observations & \multicolumn{3}{|c|}{7} \\
\hline Cross-sections & \multicolumn{3}{|c|}{17} \\
\hline $\begin{array}{l}\text { Total pool (balanced) } \\
\text { observations }\end{array}$ & \multicolumn{3}{|c|}{119} \\
\hline$R$-squared & \multicolumn{3}{|c|}{0.5882} \\
\hline Adjusted $R$-squared & \multicolumn{3}{|c|}{0.5567} \\
\hline S.E. of regression & \multicolumn{3}{|c|}{0.1328} \\
\hline Durbin-Watson stat & \multicolumn{3}{|c|}{1.8518} \\
\hline F-statistic & \multicolumn{3}{|c|}{14.1517} \\
\hline Prob (F-statistic) & \multicolumn{3}{|c|}{0.0000} \\
\hline
\end{tabular}

Note: * White standard errors and covariance (d.f. corrected). 


\section{DISCUSSION}

The regression results prove that the leverage ratio has a negative and significant impact on ERC, indicating that the market is less responsive to the change in the companies' earnings with higher leverage than the companies with the higher leverage ratio. Market participants will respond negatively because they assume that creditors will acquire most earnings in highly leveraged companies. This finding is consistent with the results of several previous studies, such as Mulyani et al. (2007), Etty (2008), and Arifin (2017).

As a measure of systematic risk, Beta coefficient has a negative and significant impact on the Earnings Response Coefficient. This indicates that high systemic risks reduce the Earnings Response Coefficient. This indicates that high systemic risks reduce Earnings Response Coefficient. This may reflect that the company's high risk witnessed lower demand on its stocks in the market, thus reducing ERC. This may also reflect the short-term investment policy for the risk-averse investors in Amman Stock Exchange who are looking for short-term and safe investments. This finding is consistent with several previous studies, such as Easton and Zmijewski (1989), Mulyani et al. (2007), and Rofika (2015), which found that systemic risk had a negative impact on the value of the Earnings Response Coefficient.

Contrary to expectations, the company size has no significant impact on ERC. This result may indicate the irrelevance of the relationship between the size of Jordanian industrial companies and their profits, making the market response not associated with the company size but with the size of the declared profits. This finding is consistent with the findings of Rizki and Rosyidiana (2017) and Suwarno et al. (2017) who suggested a significant market response to profits declared by large companies. This finding also contradicts the results of Kusuma et al. (2010) who emphasized the positive relationship between the company size and ERC.

Growth opportunity has a negative and significant impact on ERC, indicating that low market-to-book ratio (higher growth opportunity) leads to higher ERC. This result is consistent with what is expected and with the results of several previous studies, such as Andyani and Mulyani (2007), which found that the low market-to-book ratio reflects higher growth opportunities, and, therefore, ERC would be higher.

Finally, the company profitability, measured by ROA, has a positive and significant impact on ERC, indicating a higher market response for more profitable companies. These results contradict the results of some previous studies, such as the study of Suwarno et al. (2017), which confirmed that the company profitability has a negative and important impact on ERC. This result can be justified by the fact that a high return on assets reflects the company's high profitability, which forms an incentive for the investors to increase demand for the stock, increasing market response and raise of ERC.

\section{CONCLUSION}

This study aimed to examine the factors affecting the Earnings Response Coefficient in Jordan based on a sample of 17 industrial companies in Jordan listed in Amman Stock Exchange during 2012-2018. The study employed five independent variables, namely, leverage ratio, systemic risks, company size, growth opportunities, and the company's profitability.

The results of this study showed that ERC of the Jordanian industrial companies is relatively low and reflects a low market response to the profits declared by the company. The low ERC reflects the profits' inability to provide important information to the investors (Ambarwati, 2008).

Regression results confirmed that leverage ratio, systemic risks, and market-to-book value ratio have a negative and significant impact on ERC. Return on assets had a positive and significant impact on ERC.

Based on the study results, improving ERC may have a significant impact on earnings quality, thus providing important information to investors to make investment decisions and contribute to improving 
the pricing efficiency of the financial market in general. Companies can enhance ERC by seeking to reduce their leverage ratio, trying to maximize their profitability. It is also important to exert further efforts that assist in raising investors' awareness, educate them on how to build rational investment decisions based on the available information about the share. The study also recommends that it is important to conduct further studies exploring ERC in other sectors in the financial market.

In light of the importance of $\mathrm{ERC}$, as a measure of the market response to the information related to the profits, and because it is an important indicator of the quality of the profits, the higher ERC indicates higher profits quality, and it becomes important to examine the factors affecting ERC. The findings of previous studies show that many factors may affect ERC.

\section{AUTHOR CONTRIBUTIONS}

Conceptualization: Saad A. al-Sakini, Hanan Alawawdeh, Mahmoud Nour.

Data curation: Hanan Alawawdeh.

Formal analysis: Saad A. al-Sakini.

Funding acquisition: Sa'ad A. al-Sakini, Hanan Alawawdeh.

Methodology: Saad A. al-Sakini, Hanan Alawawdeh.

Project administration: Hanan Alawawdeh, Mahmoud Nour.

Resources: Hanan Alawawdeh.

Supervision: Mahmoud Nour.

Writing - original draft: Hanan Alawawdeh.

Writing - review \& editing: Mahmoud Nour.

\section{REFERENCES}

1. Ambarwati, Sri. (2008). Earnings Response Coefficient (ERC). Accountability, 7(2), 128-134.

2. Andayani, Nur, \& Sri, M. (2007) Factors that influence Earnings Response Coefficient for Companies listed on Jakarta Stock Exchange. Journal of Accounting and Finance. STIESIA Surabaya. Retrieved from https://journal.uii. ac.id/JAAI/article/view/386/301

3. Arfan, Antarsari, \& Ira. (2008). The effect of firm size, growth, and profitability on earnings response coefficients at manufacturing companies in Indonesia stock exchange. Accounting Studies and Researches, 50-64. Retrieved from http://jurnal.unsyiah.ac.id/TRA/ article/view/278/264

4. Arifin Lisdawati (2017). Earning on Response Coefficient in Automobile and Go Public Companies. Shirkah Journal of Economics and Business, 2(2), 215-238. https://doi. org/10.22515/shirkah.v2i2.164

5. Assagaf, A., Murwaningsari, E., Gunawan, J., \& Mayangsari, S. (2019). Factors Affecting the
Earning Response Coefficient with Real Activities Earning Management as Moderator: Evidence from Indonesia Stock Exchange. Asian Journal of Economics, Business and Accounting, 11(2), 1-14. https://doi.org/10.9734/ ajeba/2019/v11i230124

6. Chan, K., Chan, L., Jegadeesh, N., \& Lakonishok, J. (2006). Earnings quality and stock returns. Journal of Business, 79(3), 1041-1082. https:// doi.org/10.1086/500669

7. Collins, D., \& Kothari, S. (1989). An Analysis of Intertemporal and Cross-Sectional Determinants of Earnings Response Coefficients. Journal of Accounting and Economics, 11(2-3), 143-181. https://doi. org/10.1016/0165-4101(89)90004-9

8. Dechow, P., M., Kothari, S., \& Watts, R. L. (1998). The relation between earnings and cash flows. Journal of Accounting and Economics, 25(2), 133-168. https://doi.org/10.1016/ S0165-4101(98)00020-2

9. Diantimala, \& Yossi. (2008). The effect of conservative accounting, firm size, and default risk on earnings response coefficients. Journal of Accounting Research and Review, 1(1), 102-122. Retrieved from http://jurnal.unsyiah.ac.id/ TRA/article/view/281/267

10. Easton, P., \& Zmijewski, M. (1989). Cross-sectional variation in the stock market response to accounting earnings announcements. Journal of Accounting and Economics, 11(2-3), 17-42. https://doi.org/10.1016/01654101(89)90003-7

11. Etty, Murwaningsari, (2008). Some factors affect the earning response coefficient. National Symposium on Accounting.

12. Farooq, O., Shehata, N., \& Nathan, S. (2018). Earnings response coefficient in the MENA region. Applied Economics Letters, 25(16), 1147-1152. https://doi.org/10.1080/1 3504851.2017 .1403550

13. Gaio, C., \& Raposo, C. (2011). Earnings quality and firm valuation: international evidence. Accounting and Finance, 51(2), 467-499. https://dx.doi.org/10.1111/j.1467629X.2010.00362.X 
14. Hasanzade, M., Darabi, R., \& Mahfoozi, G. (2013). Factors Affecting the Earnings Response Coefficient: An Empirical study for Iran. European Online Journal of Natural and Social Sciences. Special Issue on Accounting and Management, 2(3), 2551-2560. Retrieved from http://european-science.com/eojnss/article/view/1505

15. Kurniawati, H., \& Dwimulyani, S. (2018). Determinants of Earnings Response Coefficient (ERC) and its Impact on Trading Volume. International Review of Management and Business Research, 7(4), 787-800. Retrieved from https://www.researchgate.net/ publication/329562742_Determinants_of_Earnings_Response_Coefficient_ERC_and_its_Impact_on_ Trading_Volume

16. Kusuma, I., Nugroho, \& Setiyo, J. (2010). Influence of corporate social responsibility, firm size and profitability to earnings response coefficient. Accounting Review, 127-148.

17. Lev, B. (2003). Corporate earnings: Facts and fiction. The Journal of Economic Perspectives, 17(2), 27-50. https://doi. org/10.1257/089533003765888412

18. Mashayekhi, B., \& Aghel, Z., (2016). A Study on the Determinants of Earnings Response Coefficient in an Emerging Market. World Academy of Science, Engineering and Technology International Journal of Economics and Management Engineering, 10(7), 2479-2482. Retrieved from https://www.researchgate.net/ publication/332249635_A-Studyon-the-Determinants-of-Earnings-Response-Coefficient-in-anEmerging-Market

19. Mulyani, S., Nur, F. A., \& Andayani, A. (2007). Factors that influence Earnings Response Coefficient on Companies Listed on the Jakarta Stock Exchange. Indonesian Journal of Accounting and Auditing, 11(1), 35-45. Retrieved from https://www. neliti.com/publications/73593/ faktor-faktor-yang-mempengaruhiearnings-response-coeficient-padaperusahaan-yan

20. Naimah, Zahroh, Utama, \& Siddharta. (2006). Influence of firm size, Growth, profitability to earnings response coefficient and coefficient Response of Equity Book
Value: Study at manufacturing company in Indonesia Stock Exchange. National Symposium on Accounting, 23-26.

21. Pamungkas \& Bayu. (2014). The influence of the size of the public accountant firm, firm size, profitability, and leverage to earnings response coefficients (empirical studies in manufacturing companies listed on the Indonesian stock exchange) (Doctoral Dissertation). University of Muhammadiyah Surakatar.

22. Paramita, R. W. D. (2012). Firm Size Effect of Earnings Response Against Coefficient (Erc) By Voluntary disclosure As an intervening variable (Study at Manufacturing Companies Listed In Indonesia stock exchange). Journal Wigan, 2(1), 64-78. Retrieved from https://media.neliti.com/media/ publications/36635-ID-pengaruhfirm-size-terhadap-earningsresponse-coeffisient-erc-denganvoluntary-d.pdf

23. Peasnell, K., V., Pope, P., \& Young, S. (2000). Accrual management to meet earnings targets: UK evidence pre-and post-Cadbury. The British Accounting Review, 32(4), 415-445. https://doi.org/10.1006/ bare.2000.0134

24. Rizki, A., \& Rosyidiana, R. (2017). Earning Quality after IFRS Adoption: Study on Indonesian Go Public Companies that are Listed On IDX. Asia Pacific Journal of Advanced Business and Social Studies, 3(2), 90-107. https://doi. org/10.25275/apjabssv3i2bus9

25. Rofika. (2015). Factors Affecting ERC in Manufacturing Companies listed on the Indonesia Stock Exchange in 2012. Journal of Accounting, 3(2), 174-183.

26. Sandi, K. U. (2013). Factors Affecting Earnings Response Coefficient. Accounting Analysis Journal, 2(3). Retrieved from https:// journal.unnes.ac.id/sju/index.php/ aaj/article/view/2847

27. Santoso, G. (2015). Determinants of Response Gain Coefficient. Parsimonia Science Program Accounting Ma Chung University. Malang, 2(2), 69-85. Retrieved from https://jurnal.machung.ac.id/index. php/parsimonia/article/view/21
28. Schipper, K., \& Vincent, L. (2003). Earnings Quality. Accounting Horizons, 17, 97-110. Retrieved from https://www.questia.com/ library/journal/1G1-105368177/ earnings-quality

29. Scott, W. R. (2015). Financial Accounting Theory (7th ed.). Toronto: Pearson.

30. Shah, S., \& Hussain, Z. (2012). Impact of ownership structure on firm performance evidence from non-financial listed companies at Karachi Stock Exchange. International Journal of Finance and Economics, 84, 6. Retrieved from https://www.researchgate.net/ publication/220024471_Impact_of_ Ownership_Structure_on_Firm_ Performance_Evidence_from Non-Financial_Listed_Companies_ at_Karachi_Stock_Exchange

31. Sharpe, W. F. (1964). Capital asset prices: A theory of market equilibrium under conditions of risk. Journal of Finance, 19, 425-442. Retrieved from http://efinance.org. $\mathrm{cn} / \mathrm{cn} / \mathrm{fm} /$ Capital\%20Asset $\% 20$ Prices\%20A\%20Theory\%20of\%20 Market\%20Equilibrium\%20 under $\% 20$ Conditions $\% 20$ of $\% 20$ Risk.pdf

32. Siegel, G. J. (1982). The Quality of Earnings concept - A Survey. Financial Analysts Journal, 38(2), 60-68. https://doi.org/10.2469/faj. v38.n2.60

33. Suwarno, Tumirin, \& Zamzam (2017). Influence of Size, Growth and Profitability of Company to Earnings Response Coefficient. International Journal of Advanced Research (IJAR), 5(12), 1463 1472. https://doi.org/10.21474/ IJAR01/6107

34. Wang, J., \& Yang, W. (2013). The Study on Listed Company Earnings Quality Analysis. School of Economics and management. Henan polytechnic university P.R. China.

35. Widiatmoko, J., \& Indarti, M. (2019). The Determinants of Earnings Response Coefficient: An Empirical Study for The Real Estate and Property Companies Listed on The Indonesia Stock Exchange. Accounting Analysis Journal, 7(2), 135-143. Retrieved from https:// journal.unnes.ac.id/sju/index.php/ aaj/article/view/27321 